\title{
AZ ÉLETHOSSZIG TARTÓ TANULÁST BEFOLYÁSOLÓ TÉNYEZŐK VIZSGÁLATA AZ IPOO-MODELL ASPEKTUSÁBÓL EGY SZAKGIMNÁZIUMBAN
}

Szerzők:

Gőgh Előd

Eszterházy Károly Egyetem (Magyarország)

Kővári Attila $(\mathrm{PhD})$

Dunaújvárosi Egyetem (Magyarország)

Első szerző e-mail címe:

goghtu@gmail.com
Lektorok:

\author{
Katona József $(\mathrm{PhD})$ \\ Dunaújvárosi Egyetem (Magyarország) \\ Ujbányi Tibor \\ Dunaújvárosi Egyetem (Magyarország)
}

Gőgh Előd és Kővári Attila (2019): Az élethosszig tartó tanulást befolyásoló tényezők vizsgálata az IPOOmodell aspektusából egy szakgimnáziumban. Különleges Bánásmód, 5. (4). 57-68.

DOI $\underline{10.18458 / K B .2019 .4 .57}$

\section{Absztrakt}

Az élethosszon át tartó tanulással kapcsolatosan alkotott helyes nézetek kialakítása nem csak minden tanár, pedagógus, oktató egyik célja kell hogy legyen, hanem nemzeti és nemzetközi stratégiák is rögzítik (Keretstratégia, 2014). A tapasztalatok azt mutatják, hogy a képzésekben részt vevő tanulók egy része, nem minden tekintetben látja ennek fontosságát. Egy, az élethosszig tartó tanulás egyes tényezőit tanulói szempontból elemző kutatás vizsgálta és értékelte az eltérő korcsoportokba tartozó tanulók erről alkotott véleményeit (Gőgh, 2018). A vizsgálat egyik fő célja az volt, hogy feltérképezze, mik azok a tényezők, amikkel a diákok szembesülnek az élethosszig tartó tanulás vonatkozásában, mik azok a momentumok, amelyek leginkább elveszik a kedvüket a tanulástól és melyek, amik leginkább motiválhatják őket. Az IPOO tanulási modell szemszögéből nézve a kapott válaszok és levonható konzekvenciák is más, egyértelmúbb megvilágításba kerülhetnek ezért érdemes megvizsgálni azokat ebből a megközelítésből. A vizsgálat eredményei egy kérdőívesvizsgálatból adódnak $(n=378)$, amely az adatfelvételben részt vett intézmény, a BGéSZC Kossuth Lajos Két Tanítási Nyelvú Múszaki Szakgimnáziuma, esetében reprezentatívnak mondható.A diákok őszinte válaszain azért érdemes elgondolkodni, mert az intézményi szinten és általánosságban is olyan konzekvenciákat tartalmazhatnak, amelyekkel a tanulási motivációk és a tanulási hajlandóság ispozitív irányba befolyásolható, amely az élethosszig tartó tanulás szempontjából alapvető.

Kulcsszavak: életen át tartó tanulás, tanulási motivációk, szakképzés, IPOO-modell

Diszciplina: pedagógia

\section{Abstract}

Developing good views on lifelong learning should not only be one of the goals of all teachers, but also national and international strategies. Experiences, how that some of the students participating in the training do not see the importance of this in all respects. A study analyzing individual factors of lifelong learning from the student's point of view examined and evaluated the opinions of students of different age 
groups (Gögh, 2018). One of the main goals of the study was to explore the factors that students face with regard to lifelong learning, those factors that are most likely to lose their pleasures from learning and which can motivate them. From the point of view of the IPOO learning model, the resulting responses and deductible consequences may also be more clearly illuminated, so it is worth examining them from this approach. The results of the study are from a questionnaire based study $(n=378)$, which is representative of the institute participating in the survey, the BGéSZC Kossuth Lajos Bilingual Vocational Secondary School of Technology. It is worth thinking about the honest responses of students because they can include consequences on the institutional level and in general, with which learning motivations and willingness to learn can also be influenced in a positive direction that is essential for lifelong learning.

Keywords: lifelong learning, learning motivations, vocational training, IPOO model

Disciplines: pedagogy

Az élethosszig tartó tanulás, mint fogalom a kifejezésból adódóan a tanulási folyamatok szinte minden formáját lefedi életkortól függetlenül. A kutatás témájaként elsősorban ennek a folyamatnak a középfokú szakmai képzéseket nyújtó szegmensére fókuszálunk. A középfokú oktatásban ugyanakkor nem csak a középiskolások, hanem felnőttek is részt vesznek így az egész életen át tartó tanulás középfokú szinten is folytatható életkortól függetlenül.

$\mathrm{Az}$ élethosszig tartó tanulás meglehetősen releváns prioritású napjainkban nemzetközi szinten is. Magyarország az Európai Unió tagjaként megalkotta az erre vonatkozó keretstratégiát, amely aktuálisan a 2014-2020-as időszakra vonatkozó helyzetet és teendőket öleli fel.A stratégia szerint az egész életen át tartó tanuláshoz szükségesek bizonyos alapkészségek és kulcskompetenciák úgy, mint írás, olvasás, számolás, kommunikáció (IKT, idegennyelv-tudás) döntésképesség, munkaszervezetben való részvétel képessége, önálló tanulási képesség, egészségtudatosság, stb., illetve az alapkészségeket kiegészító azon kompetenciák összessége (Keretstratégia, 2014). Ezek teszik az egyént képessé arra, hogy új tudásra tegyen szert, illetve hogy tudását az új követelményekhez hozzáigazítsa.

Jelenleg a regisztrált felnőttkori tanulásban résztvevők hagyományosan és töretlenül elsősorban a szakmai irányultságú képzésekben bővítik is- mereteiket. A képzések irányultságát tekintve elsősorban a szakmai képzés, szakképesítésre irányuló továbbképzés dominanál, ezt követik az OKJ-s képzések, majd a nyelvi képzések, illetve az általános célú felnőtttépzések (Keretstratégia, 2014).

Ennek megfelelően a szakképzés is átalakításra került, mivel a szakképzési rendszer kibocsátása egyre távolabb került a munkaerôpiac valós igényeitôl. A megoldást egy koherens, átfogó, új szakképzési törvény jelenti (2011. évi CLXXXVII. törvény a szakképzésrőll).

$\mathrm{Az}$ európai uniós célokkal összhangban a szakképzés megújításának célja, hogy erősítse a gazdaság szerepét, ezáltal javítva a szakképzésből kilépők elhelyezkedési esélyeit és a munkaerő versenyképességének javítását.

A képzés tartalmi fejlesztése magában foglalja a tananyagok, a vizsgarendszer fejlesztését, az Országos Képzési Jegyzék felülvizsgálatát, és az új szakképzési kerettantervek kidolgozását. A szakiskolai képzés tartalmának megújitásával párhuzamosan kerül bevezetésre és elterjesztésre a duális képzés kiterjesztése. Azaz Magyarországon is jelentős erőfeszítések történtek már az élethosszig tartó tanulás előmozdításának érdekében. Az idézett keretstratégia időtartama lassan a végéhez ér és valóban tapasztalható számos olyan változás, amely elősegíti a minden életszakaszban és mindenki számára elérhetô tanulást. 
Az említett szakképzési törvényben foglaltak alapján Magyarországon az első és második szakképesítés megszerzését az államingyenesen biztosítja a szakképző iskolai tanulók számára. Természetesen már csak ez jelentős lökést adhat a szakképzésbe bevonhatók körét illetően. Ennek megfelelôen az ilyen képzést nyújtó intézményekben az esti rendszerû képzésekben is jelentős számú tanuló számára válik lehetôvé a tanulás, olyan szakma megszerzése, amelyet a későbbiekben hasznosítani szeretnének ezek a diákok, általában felnőttek.

Az intézményrendszer is átalakításra került és a korábbi szakközépiskolák szakgimnáziumokká váltak, valamint a szakképzés és a gazdaság kapcsolatát is mutatja, hogy a szakképzési intézmények (szakközépiskolák, szakgimnáziumok) a Nemzetgazdasági Minisztérium alá kerültek (majd 2018-tól az Innovációs és Technológiai Minisztérium alá) és a korábbi KLIK-eket ezen intézmények esetében szakképzési centrumok váltották fel, hatékonyabb múködéssel és a szakképzésre jobban fókuszálva (Palotás, 2016).

Ezzel párhuzamosan komoly változást jelent a szakmai érettségi vizsgák újbóli bevezetése (NSZFI, 2018). A 2017-ben indult új rendszer legfontosabb ismérve, hogy akik sikeresen teljesítik a vizsgakövetelményeket, szakmát is szereznek, hiszen érettségi bizonyítványukba záradék kerül, amely tanúsítja szakképzettségüket, továbbá meghatározott munkakör betöltésére jogosítja fel a végzett diákokat. A szakmai érettségi nagy elónye, hogy a szakmai érettségi megszerzése egyúttal többletpontot jelenthet számukra a felsőoktatásba történő jelentkezés esetén. Ugyanakkor az ágazati képzést folytatva a korábban általában a régi szakközépiskolai képzésre épülő két éves OKJ-s képzések 1 év alatt is elérhetővé válnak. A szakmai kerettantervek rögzítik ennek feltételeit, tehát az ágazatban maradva a szakgimnáziumok 4+1 évessé válnak ebben az esetben (HVG Eduline, 2017). A korábban az $1 / 13$. tanév tantárgyait ugyanis teljes egészében lefedik az ágazati szakmai érettségi vizsga követelményeit jelentő tantárgyak (HVG Eduline, 2017).
A felnőttek számára az említetteken kívül az elmúlt években lehetőség volt a kis- és középvállalkozások ügyvezetője I-II. képzések három szakmai - nyelvi, informatikai, vezetôi ismeretek - tartalmakkal.

Ezek a képzések rendkívül népszerúek voltak a felnőttek körében elsősorban a nyelvi képzési lehetőség szempontjából.

Részben ezeket helyettesítik az ingyenes nyelvi képzések, amelyek egy európai uniós projekt keretében, „Idegen nyelvi készségek fejlesztése” címmel ingyenes angol és német nyelvi tanfolyamokat jelentenek és a középfokú végzettséggel rendelkezőket célozzák meg (BGSZC, 2017).

Mindezen változások tudatában értelmesnek tűnik mérni ezek hatását a tanulók, képzésben részvevők körében a szakgimnáziumokban.

\section{Az IPOO-modell}

$\mathrm{Az}$ IPOO-modellszerint amennyiben a tanulásaz információkkal való múveletek egyfajta folyamatának tekinthető, úgy az információkezelés egyes fó fázisai (1. ábra, Mező, 2005):

- információgyüijtés (input)

- információfeldolgozás (process)

- információalkalmazás, felhasználás (output) és

- az előzőek hatásfokát meghatározó tanulásszervezés (organizáció)

Az 1. ábrán látható modellben a tanulásszervezés szorzati viszonyban áll a másik három tényező összegével. Ennek az a magyarázata, hogy ha megfelelő is a tanulásszervezés, de nem megfelelően bánunk az információkkal, akkor az eredményesség alacsony (Mező, 2011). Ennek a fordítottja is igaz, a szervezetlen tanulás nem vezet igazi eredményre.

Mindegyik összetevôt az ismeretek, képességek, motívumok és módszerek befolyásolják, ezek kapcsolata az aktuális tanulási helyzettel összefüggésben van a tanulás sikerességével. A modell ezeknek az összefüggésnek a leírását foglalja magában. 


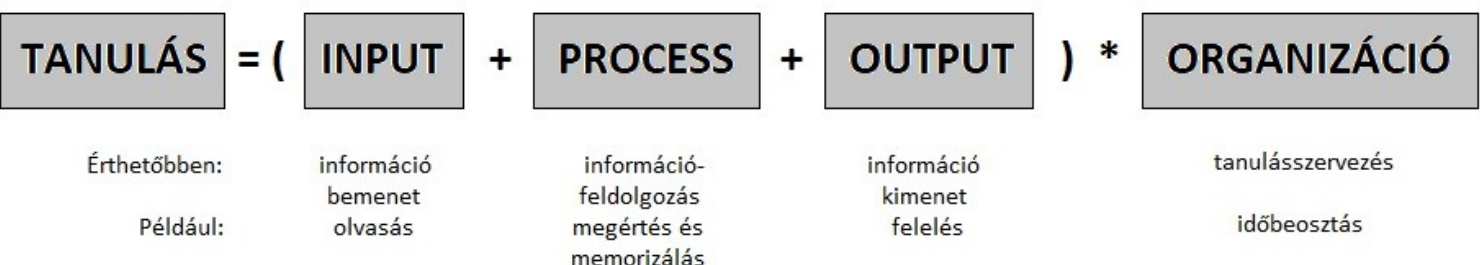

\section{Az IPOO-modell és az élethosszig tartó tanulás kapcsolata}

Az élethosszig tartó tanulás fogalmának és az IPOO-modell kapcsolatának vizsgálatakor érdemes az előbbi esetében tanulási folyamatként szemlélni azt.

Az információgyütési sqakasłhoz egyrészt hozzátartoznak azok a tényezők, amik általában és összességében a tanuláshoz tartoznak, ugyanakkor tágabb értelemben az is, hogy a képzésben részt vevő tanulóknak, valamint a potenciálisan tanulási folyamatban, oktatásban részt vevőknek van-e fogalmuk arról, hogy az élethosszig tartó tanulásnak mi a haszna, hogyan segíti későbbi boldogulásukat. Tudatában vannak-e annak, hogy napjainkban munkák, munkatípusok szűnnek meg és keletkeznek újak, akár strukturális munkaerőhiányt teremtve. Ezek eredménye az átképzés vagy új szakmák elsajátítását vonhatja maga után. Szűkebb értelemben a munkaerőpiacon való helytállás is megköveteli a naprakész ismereteket, sőt a munkáltató kötelessége a dolgozóinak szakmai ismeretekkel való bővítése és esetleges továbbképzéseken való részvételük biztosítása. A másik oldalon a munkavállalónak pedig ez ezeken való részvétel és megfelelő szinten helytállás. Az élethosszig tartó tanulással összefüggésben az olyan tényezőket sorolhatjuk ehhez a fázishoz, amik bemenetként már jelen vannak a tanulók esetében és kiindulási alapot nyújtanak (vagy pozitív vagy negatív irányban) a tanulási folyamathoz.

$\mathrm{Az}$ információfeldolgozási szakaşhoz tartozik tágabb értelemben az összes olyan tevékenység, amely az élethosszig tartó tanulást eredményezheti. Azaz az élethosszig tartó tanulásról kapott információkkal vagy ha ezek nincsenek jelen, akkor a tanulóknál bizonyos motivációs tényezők eredményeképpen juthatnak el az élethosszig tartó tanulás megvalósulásáig. A tanulásit segítő vagy gátló tényezők esetében azokat lehet ennél a fázisnál megemlíteni, amik a tanulási folyamathoz kapcsolódóan vannak hatással az élethosszig tartó tanulásra.

Az információalkalmazás, felhasználás szakaszában mérhetjük azt le, hogy az élethosszig tartó tanulás jelen van-e vagy sem. Nyilvánvalóan a fogalomból adódóan erre csak árnyalt választ kaphatunk. Érdemesebb inkább olyan motivációs és tanulási tényezőket ide sorolnunk, amelyek végső kimenete az élethosszig tartó tanulás segítése és erôsítése.

A tanulásszervezési szakasz̧oz az összes olyan tényező tartozhat, amely oktatáspolitikai szempontból hatást gyakorol az egész életen át tartó tanulásra és amelyekre a bevezetőben részletesen kitértünk. Illetve azok, amik az iskolai tevékenységhez, a tanárok munkájához kapcsolódó tényezők.

\section{Egy élethosszig tartó tanulással összefüggő vizsgálat az IPOO-modell tükrében}

Egy, az élethosszig tartó tanulást többféle szempontból megközelítő kérdéssorral a diákok tanulási motivációs tényezőire irányult a kérdések egy csoportja.A motivációs tényezőkön belül a legfőbb szempont annak a feltérképezése volt, hogy kiindulási alapként mik azok a tényezők, amik jelen 
KÜLÖNLEGES BÁNÁSMÓD, V.ÉVF. 2019/4.

vannak a diákok esetében, mint a tanulási kedvet meghatározó, segítő és gátló aspektusok.Mindezt az IPOO tanulási modellre vetítve a kapott tényezők a modell mely fázisaiban jelennek meg és hogyan hathatnak a további tanulási modell elemekre.

Összességében a kapott tanulási tényező IPOO modell-szakaszhoz rendelése után az élethosszig tartó tanulást egy más megközelítésből láthatjuk, amely jobban segitheti az egyes tényezők rendszerben való szemléletét és az élethosszig tartó tanulás vonatkozásában is segítheti ezek fejlesztését.

A két tanulási tényezőkre pro és kontra irányban ható halmazok alapján a cél, ha kell a segítő motivációs elemek további erősítése és erre irányuló pedagógiai lépések kidolgozása, valamint a demotivációs elemek redukálása, hátterük vizsgálata és a szükséges intézkedésekre irányuló stratégiák kidolgozásának segitése.

A fenti motivációs és demotivációs elemek azonosítása és megfelelő irányba történő irányítása nyújthat alapot az élethosszig tartó tanulás alapjainak megvalósításához.

\section{A vizsgált minta}

A vizsgálat egy kérdéssor segítségével történt, elsősorban (egy csoport kivételével) a BGéSZC Kossuth Lajos Két Tanítási Nyelvű Mû́szaki Szakgimnáziumának diákjainak véleményét rögzítette. Ennél fogva országosan és intézménytípusra vonatkozóan sem nyújt reprezentatív alapot, intézményi szinten viszont igen. Hang-súlyozandó ugyanakkor, hogy a válaszok kizárólag a diákok véleményét tükrözik, a kitöltés és a válaszok pedagógusok és oktatási szakemberek véle-ményét nélkülözik. Az eredmények tekintetében kizárólag a diákok tanulási tényezőire irányult a vizsgálat.

Mivel a BGéSZC Kossuth Lajos Két Tanítási Nyelvú Műszaki Szakgimnáziumában mint középfokú képző intézményben is többféle képzés zajlik egyszerre, legtriviálisabb bontásban is az érettségi előtti szakgimnáziumi osztályokat és az érettségit követô OKJ-s szakmákat említve, nyilvánvaló, hogy a válaszadókat nem lehet egységesen kezelni. Ezért az intézmény tanulóit hét különböző csoportot alkotva különítettük el (1. táblázat).

1. táblázat. Vižsgált minta megoszlása. (Forrás: Sžerző̉k).

\begin{tabular}{|l|c|c|c|}
\hline \multicolumn{1}{|c|}{ Csoportnév } & Kitöltésszámok & $\begin{array}{c}\text { Lehetséges } \\
\text { kitöltők }\end{array}$ & $\begin{array}{c}\text { Kitöltési } \\
\text { arány }\end{array}$ \\
\hline 9-11. évfolyamon tanulók & 155 & 380 & $41 \%$ \\
\hline 12. évfolyamos, érettségiző tanulók & 66 & 90 & $73 \%$ \\
\hline 13. évfolyam szakképzősök & 37 & 50 & $74 \%$ \\
\hline Esti rendszerben 13. évfolyamon tanulók & 28 & 42 & $67 \%$ \\
\hline $\begin{array}{l}\text { Végzős (estis és nappalis) szakképzôs } \\
\text { tanulók }\end{array}$ & 65 & 72 & $90 \%$ \\
\hline KKV-s képzésben részvevók & 13 & 17 & $76 \%$ \\
\hline $\begin{array}{l}\text { Pénzügyi-számviteli ügyintézó tanfoly- } \\
\text { amon tanulók (nem BGéSZC) }\end{array}$ & 14 & 22 & $64 \%$ \\
\hline ÖSSZESEN & $\mathbf{3 7 8}$ & 673 & $56 \%$ \\
\hline
\end{tabular}


A csoportalkotás elsősorban a képzési folyamat szakaszai alapján történt, ami természetesen majdnem teljes életkori szakaszokat is jelent egyben. Tehát kiindulási hipotézisként azt feltételeztük, hogy az életkor alapján is más-más tényezők befolyásolják a tanulási kedvet. Ezt a kezdeti feltevést az eredmények is igazolták.

\section{A kérdőív elemei és kiértékelése}

A legjelentősebb segítő és gátló tanulási tényezőkre irányuló kérdések tekintetében a válaszok nem irányítottan történtek, hanem a nyitott kérdésre szövegesen, mindenfajta megkötés nélkül válaszolhattak a kitöltők.

A konkrét kérdések az alábbiak voltak:

- Írja le egy mondatban, hogy mi lenne az, ami teljesen biztosan motiválná a tanulásra, tehát mindenképpen tanulna:

- Írja le mi az ok vagy okok, amik elveszik a kedvét a tanulástól:

Azaz a legjelentősebb, a diákokat leginkább motiváló és demotiváló tanulási tényezőkre irányultak a kérdések.

A kiértékelés a válaszok elemzésére irányult elsősorban arra, hogy az IPOO-modell egyes szakaszaiban mely tanulást befolyásoló tényezőt azonosíthatjuk. A szöveges válaszokat eredményező kérdések feldolgozása az adatok kvalitatív mivolta miatt előzetes feldolgozást igényelt. A különböző válaszok egyenkénti tanulmányozása alapján kategóriákba sorolhatók, mely a kiértékelés során összegzésre, csoportosításra került.

\section{Eredmények}

$\mathrm{Az}$,Írja le egy mondatban, hogy mi lenne az, ami teljesen biztosan motiválná a tanulásra, tehát mindenképpen tanulna:" kérdés válaszaiból az alábbi főbb kategóriák voltak meghatározhatók (rövid magyarázattal):

- külföldi karrier: a tanulás célja elsősorban a külföldi munkavégzésre irányul hosszú távon, jelenleg a nyelvtanulás is erős motivációt jelent
- újabb képzettség szerzése: a cél az, hogy az illető válaszadó több szakmai képzettséggel rendelkezzen, amelyekkel nagyobb valószínűséggel helyezkedhet el a munkaerőpiacon hosszútávon. Illetve a különböző képzettségekkel erősebb össztudással bírhat, ami az egyenként vett szakmákban is kamatoztatható, nem csak külön-külön.

- életcél(ok) megvalósítása: olyan tanulási háttérokot jelent, ahol a tanuló már régóta készül a szakmai karrierre és az abban való elhelyezkedésre. Ugyanakkor olyan későbbi a szakmához részben kapcsolódó célokat is jelent, amelyek csak részben kapcsolódnak a szakmához.

- ösztöndíj: a képzési folyamat alatti pénzügyi forrást jelenti

- nagyobb fizetés elérése: hosszútávú célként a szakmai elhelyezkedésből adódó és megszerezhetô, a többi szakmához képest magasabb fizetésre irányul

- szakmai érdeklődés: tisztán a szakma iránti vonzódásból adódó motiváció, hasonló az „életcél(ok) megvalósításához”, azonban szűkebb értelemben értendő

- hasznos tudás megszerzése: a diákok esetében gyakran megkérdőjeleződik bizonyos tantárgyak, tudásrészek későbbi hasznosíthatósága. Ez a válasz kategória arra irányul, hogy valóban hasznosítható, a tanuló számára a képzési folyamatban átláthatóan „értelmes” tudást preferálják a diákok.

- tanulásért magáért: az élethosszig tartó tanulásnak megfelelô, az egyéb motivációs tényezőktől csak kevéssé összefüggő olyan cél, amely elsősorban az információszerzésre irányul.

- korrekt osztályozás: a tanulók gyakran panaszkodnak arra, hogy a nem konzekvens vagy nem a tudást tükröző alkalmazott mérésértékelési rendszerek eredményeképpen kapott rossz osztályzatok erősen motivációvesztő hatásúak.

A kapott válaszok annak megfelelőek, hogy ha az előbbi nem áll fenn, akkor a diákok sokkal 
motiváltabban tanulnának (mert jobban és kiszámíthatóbban látják annak eredményét).

- továbbtanulás: valamilyen továbbtanulás cél miatti tanulási motivációt takar

- jó osztályzatok szerzése: azt jelenti, hogy a tanulók tudása, ha alkalmanként akár kissé felül is van értékelve, ez olyan folyamatokat eredményez, amik után szívesebben tanulják az adott tantárgyakat.

- siker/karrier érzése: a dicséret, a megérdemelt tanulási munka eredményének érzését jelenti, de ennél sokkal többet is. hosszútávon a karriercélok elérését. Részben hasonlít a „jó osztályzatok” és az „életcél(ok) elérése” kategóriákhoz, azonban deklaráltan ezeket a válaszokat mutatva önálló kategóriaként.

- biztos megélhetés: olyan célt jelent, amelynek a végső eredménye a biztos és kiszámítható anyagi megélhetés. Magába foglalja azt is, hogy várhatóan nem kell teljesen átképeznie és új szakmát tanulnia a későbbiekben a válaszadónak.

- oktatásból eredő hibákon változtatás: azokat a válaszokat foglalja magába, amelyek az iskolarendszerből adódó problémákat jelentik, mint pl. a túlzott lexikális tudásra építő módszerek vagy a képzés szerkezetéből a diákokon lecsapódó negatív tapasztalatok. Semmiképpen sem intézményi szintű problémákról van szó. Az ezeken történő változtatások a diákok nagyobb motiváltságát eredményeznék, ezt fejezték ki a diákok ebbe a kategóriába sorolható válaszaikkal.

- egyéb: olyan a fenti tényezőkbe nem sorolható válaszok tartoznak ide, amelyek vagy egyediek, vagy a feltett kérdés félreértéséből adódóan válaszként nem értelmezhetők.

A másik, a tanulási demotivációt okozó tényezők feltérképezésére irányuló, „Írja le mi az ok vagy okok, amik elveszik a kedvét a tanulástól:” kérdésre adott válaszok feldolgozása az előzőekben leírtakkal azonos. A kapott tényezők, rövid magyarázatukkal az alábbi főbb kategóriákba sorolhatók:
- időhiány: a tanulásra fordítható idő a kiváltó oka a meghiúsulásnak

- családi ok: olyan háttérok, ami elsősorban felnőtt tanulók esetében a gyerekneveléssel vagy valamilyen más családi és magánéleti vonatkozással függ össze

- már elegendő a tudás: a válaszadó a már meglévő képzettségeit elegendőnek tartja ahhoz, hogy a munka világában már a tisztán szakmai előrehaladásával boldoguljon és nem érzi szükségét további, képzési rendszerben megvalósuló tudásszerzésnek

- tanulás utálata: valamilyen más okból a tanulási motiváció olyan alacsony, ami szinte teljes egészében a kedvét szegi

- minél előbbi pénzkeresés inkább: az adott képzés elvégzésére összpontosít a válaszadó és arra, hogy ezt azonnal hasznosíthassa elsősorban anyagi szempontok miatt

- túl sok tananyag: összefügg a szakgimnáziumi képzések sokszor heti 40 tanórás túlterheltségével is. A diákok sokszor érzik úgy, hogy a tananyag olyan sok és/vagy annyi tantárgyból kell egyszerre helytállniuk, hogy felaprózódik a tanulásba fektetett idejük és a motivációjuk jelentősen csökken.

- nincs anyagi vonzata: arra irányul a kategória, hogy a megszerzett tudás várhatóan, a diákok mérlegelése szerint anyagi szempontból nem kifizetődő. Azaz hiába tanulnak adott tantárgyakat, szereznek tudást, a tanulásba belefektetett energia anyagi haszonnal nem fog járni.

- pénzügyi nehézségek: egyrészt azt takarja, hogy ha fizetni kell a képzésért, akkor a tanuló nem tudja elöteremteni hozzá az anyagi forrást. Másrészt, ha a már megszerzett tudással elhelyezkedne, akkor lenne anyagi forrás, viszont lehet, hogy emiatt a tanulásra fordítható idő lenne az akadályozó tényező.

- oktatási rendszer hibái miatt: az olyan, nem intézményi szintű problémákat jelenti, amik az oktatás rendszeréhez, a képzési rendszerhez alapvetően kapcsolódnak. Ide értendők azok a 
múltbéli negatív tapasztalatok, amik a jelentős motivációvesztést okozták.

- lustaság: a tanulást akadályozó, tanulók által egyértelmúen válaszként szereplő ok

- hasznosíthatatlan a megszerzendő tudás: a diákok esetében gyakran megkérdőjeleződik bizonyos tantárgyak, tudásrészek későbbi hasznosíthatósága. Ez a válasz kategória arra irányul, hogy valóban hasznosítható, a tanuló számára a képzési folyamatban átláthatóan „értelmes” tudást preferálják a diákok, nem szívesen vesznek részt olyan tanulási képzési folyamatban, amelynek nem látják az értelmét, vagy nem tudják más tudásterületekhez kapcsolni.

- rossz jegy miatti motivációvesztés: a tanulók gyakran panaszkodnak arra, hogy a nem konzekvens vagy nem a tudást tükröző alkalmazott mérés-értékelési rendszerek eredményeképpen kapott rossz osztályzatok erősen motivációvesztő hatásúak.

- egészségi állapot: olyan külső hatás, amely a tanulással nem összeegyeztethető okként áll fenn

- munkahely miatt: elsősorban a felnőtt diákok esetében a munkahelyi kötöttségek sokszor nem engedik meg a képzésekben való részvételt.

- egyéb: olyan a fenti tényezőkbe nem sorolható válaszok tartoznak ide, amelyek vagy egyediek, vagy a feltett kérdés félreértéséből adódóan válaszként nem értelmezhetôk.

A kapott válaszok értelmezésekor fontos megemlíteni, hogy ezek lehetséges akadályozó vagy segítő tényezőket jelentenek. Azaz képzésben részt vevők véleményét tükrözik és olyan válaszok ezek, amik szerintük akadályozzák, vagy segítik a tanulásukat. Más szavakkal: pl. nem akut tanulási problémát, hanem lehetséges tényezőket említenek.

\section{A segitó tényezók csoportositása az. IPOO-modell szakaszai alapján}

1. információgyújtés (input) - bemenetként jellemzőek
2. információfeldolgozás (process) - a tanulási folyamatra hatással vannak és végigkísérik azt

- szakmai érdeklődés

- hasznos tudás megszerzése

- tanulásért magáért

- továbbtanulás

- jó osztályzatok szerzése

3. információalkalmazás, felhasználás (output) - főként motivációs célok és a tanulási folyamat eredményét jelentő tényezők

- külföldi karrier

- újabb képzettség szerzése

- nagyobb fizetés elérése

- siker/karrier érzése

- biztos megélhetés

4. az előzőek hatásfokát meghatározó tanulásszervezés (organizáció)

- korrekt osztályozás

- oktatásból eredő hibákon változtatás

Észrevehetô, hogy a segítő tényezők között az input rész üresen maradt. Ez nem azért van, mert nincsenek ilyen tényezők, hanem a kutatás jellegéből adódóan nyilvánvalóan a válaszok nem a meglévő, bázisként értelmezhető tényezőket eredményezik. Ugyanakkor az 1. és 2. szakaszhoz rendelt tényezők összemosódhatnak és adott esetben az 1.-es szakaszban is azonosíthatók.

\section{A gátló tényezók csoportositása az IPOO-modell szakaszai alapján}

1. információgyüijtés (input) - problémaként már kezdetben jellemzők lehetnek

- időhiány

- családi ok

- már elegendő a tudás

- tanulás utálata

- minél előbbi pénzkeresés inkább

- pénzügyi nehézségek

- lustaság

- egészségi állapot 
- munkahely miatt

2. információfeldolgozás (process) - a tanulási folyamatra hatással vannak és végigkísérik azt

3. információalkalmazás, felhasználás (output) - főként motivációvesztő tényezők és a tanulási folyamat negatív eredményét jelentő tényezők

- nincs anyagi vonzata

- hasznosíthatatlan a megszerzendó tudás

4. az előzőek hatásfokát meghatározó tanulásszervezés (organizáció)

- túl sok tananyag

- oktatási rendszer hibái miatt

- rossz jegy miatti motivációvesztés

\section{Következtetések}

A kapott tényezôk a csoportosítások után összességében értelmezhetők szakaszokként a gátló és segítő tényezőkkel együttesen. Ismét megemlítendő, hogy a leírás konkrét statisztikai adatok nélkül történik, mert az IPOO-modell szerinti szemlélet a hangsúlyozandó és nem a konkrét statisztikai elemzés eredményei.

\section{Információgyïtés (input) - bemenetként jellemrọée.}

A szakgimnáziumi végzős tanulók válaszának harmada az idôhiányt, másik harmada a pénzügyi nehézségeket említi, mint akadályozó tényezőt. Ez utóbbi nem feltétlenül aktuális állapotot, hanem azt, hogy ennek fennállása esetén nem tudnák folytatni az ismeretszerzésüket további képzésekkel. Harmadikként 17\%-kal megjelenik a családi ok, mint lehetséges problémalehetôség. A többi válaszkategória szinte elenyésző mértékú a legjelentősebbekhez képest.

Az esti rendszerủ képzésben részt vevők csoportja kissé eltér a nappali képzésben tanulókétól. Az időhiány a legjelentősebb akadály, viszont második legrelevánsabb kategóriaként szerepel a családi ok. Ez abból adódhat, hogy a 13-os esti képzésben részt vevők jellemzően idősebbek, mint a nappali képzésben részt vevők, akik általában az érettségi vizsgát követően kezdik meg az OKJ-s szakmai képzéseket. Azaz az idősebbek esetében a családi okok egyre inkább előtérbe kerülnek. A munkahely miatti nehézségeket és a pénzügyi nehézségeket azonos relevanciával válaszolták ezek a tanulók. Mindkettő abból adódik, hogy szinte mindegyikük munkahellyel rendelkezik már, nem engedhetik meg azt, hogy munkahely (mint anyagi forrás) nélkül vegyenek részt a tanulási folyamatban és igyekeznek helyt állni a munkájukban, hogy ne veszítsék el ezen financiális forrásukat.

\section{Információfeldolgozás (process) - a tanulási folyamatra hatással vannakés végigkisérik azt}

A diákokkal történő konzultációk és fókuszcsoportos interjúk alkalmával is, de még a tanórai azonnali visszajelzések során is gyakran előfordul a „Miért kell ezt nekem megtanulni?” kérdés. Sokszor tanárként valóban nehéz erre valós indokot találni, legtöbbször ugyanis a gondolkodásmód kialakításához is szükséges olyan tudásrészek elsajátítása, ami aktuálisan lehet, hogy lexikai jellegú, de hosszútávon kifizetődő. Arra viszont mindenképpen érdemes a pedagógusoknak figyelmet fordítaniuk, hogy lehetőség szerint a tananyagrészeket egy közös nagy képbe helyezzék és rámutassanak annak hasznosíthatóságára, legyen az elméleti vagy akár gyakorlati vonatkozású.

Ide tartozik az is, hogy az ismeretszerzés folyamata is változik a modern technológiák fejlódésével. Régebben elsősorban a könyvtárak jelentették az univerzális tudásbázist, ma már az interneten szinte minden információ elérhető. A tanulók mérésénél, értékelésénél az elkerülhető, lexikális tudást mérése helyett a diákok információkeresési, információszerzési kompetenciájának fejlesztésével hatékonyabb, hasznosabb eredményeket elérni a tanulók képzése során. Az így megszerzett, nem tisztán lexikális tudás vélhetően hosszabb távon hasznosítható a diákok részéről, mint amit már szinte a dolgozatírás idejéig tanulnak meg.

A 13. évfolyamos OKJ nappali rendszerú képzésben tanulók a legjellemzőbb válaszai alapján meglehetősen egyedi jellemzőket képviselnek. A 
nagyobb fizetés, mint legrelevánsabb válasz mellett az újabb képzettség és a szakmai érdeklődés is megjelenik.

Ez utóbbi kettő örvendetes módon a tanulással, szakmai ismeretszerzéssel függ össze, sôt az újabb képzettség szerzése válasz ennél a csoportnál a legnagyobb arányú az összes csoportot tekintve.

A 13. évfolyamos esti rendszerû képzésben tanulók csoportjában a szakmai érdeklődés a legjelentősebb arányú válasz. Ez a többi helyen álló válaszeredményekkel együttesen is értelmezhető úgy, hogy a zömében a csoport tagjai nem azonnal az érettségi vizsga után, hanem későbbi életkorban kezdi el az esti rendszerú OKJ-s képzéseket. Az itt tanuló diákok jóval motiváltabbak a nappali rendszerú képzésben részt vevő diákoknál, tanulási eredményeik is általánosan ezt tükrözik. Jellemzően olyanok jelentkeznek erre a képzésre, akik munka mellett egy újabb, hasznos szakmát szeretnének tanulni és egy tudatos döntés alapján, céljaik valamifajta megfogalmazása után választják meg mit is szeretnének tanulni. Mindegyik tényező ezt tükrözi és ez a tudatosság fedezhetô fel mindegyikben. Azaz szakmai érdeklődés alapján kiválasztott képzéssel nagyobb fizetést szeretnének elérni egy biztos megélhetés reményében. Hasznos tudást szeretnének elsajátítani, azért is választják ki tudatosan, mit fognak tanulni, felismerik, hogy fontos a tanulás és már egy szemléletváltás után „nem utálják az iskolát”, hanem felfedezték, hogy ezáltal tudják megvalósítani az életcéljaikat.

Információalkalmaz̧ás, felhasználás (output) - föként motivációs célok és a tanulási folyamat eredményét jelentó tényerök

A 9-11. évfolyamosok esetében az ösztöndíj, mint motivációs tényező lenne ennél a tanulócsoportnál a legnagyobb erejû. Fontos megemlíteni, hogy ilyen irányú válaszok a többi csoportnál vagy elenyésző mértékben (13. évfolyam OKJ, nappali rendszerú képzés) vagy egyáltalán nem érkezett. Az ösztöndíj nyilvánvalóan egy olyan kézzelfogható, a tanulmányi sikereket tovább erősítő mozgatórugó lehet ebben a korosztályban, amire érdemes támaszkodni a szakgimnáziumi tanulók esetében.
A 12. évfolyamos, azaz az érettségizők évfolyamának csoportjában a legfontosabb három tényező a biztos megélhetés, a siker/karrier érzése és a nagyobb fizetés elérése. Mindhárom hosszú távú cél és összefüggésben áll a sikerrel és az ezzel járó nagyobb fizetéssel és az így biztosítható megélhetéssel.

Úgy tűnik, a szakgimnáziumi évek befejezésével ráébrednek a tanulók arra, hogy közeleg számukra az az időszak, amikor egyre inkább a saját lábukon kell állniuk és magukra számíthatnak.

A szakmai vizsga előtt állók (a felmérés közvetlenül a megmérettetés elôtt történt) csoportjában négy jelentôs válaszeredmény mondható relevánsnak. Ezek közül a nagyobb fizetés elérése, mint cél az összes válasz negyedét teszi ki, ezt követik a szakmai érdeklődés és a tanulásért magért válaszok azonos százalékos megoszlással. Kis eltéréssel a biztos megélhetés követi mindezt.

Mind a négy jelentős válaszkategória az előző csoporthoz képest inkább a hosszútávú tervezésre irányul. Nagyobb fizetést szeretnének elérni a diákok, szakmai érdeklődésből is fakadóan szívesen tanulnak és a biztos megélhetés is a szemük előtt lebeg.

Az elöróék batásfokát megbatározó tanulásszervezés (organizáció)

Az oktatási rendszer negatív tulajdonságainak megfelelő válaszok is jelentős részt képviselnek. Ezek a hibák részben összefüggenek az előző bekezdésben leírtakkal. De ide tartozik a túlzott, sokszor heti 40 óránál több tanóra, illetve az oktatási rendszer olyan elemei, amiken némely esetben apróbb változások is nagyobb tanulási motivációt eredményeznének. Összességben az elmúlt évek változásai, amik pl. a szakgimnáziumi képzésben történtek jelentősen pozitív irányba mozdították a szakképzést, az említettek problémák inkább finomhangolást jelentenek. A diákokkal egyébként azt is célszerủ lenne megértetni, hogy bizonyos, az oktatási rendszer óket is érintő elemei miért történnek.

A szakgimnáziumi, nem végzős évfolyamú tanu-lók a hasznosíthatatlan tudást látják a legje- 
lentősebb gátló tényezőként a tanulási folyamatukban. Ez a válaszok harmadát jelenti és semelyik másik mintavételi csoportban sem ilyen jelentős ez a tényező, sôt szinte elenyésző relevanciájú.

Úgy gondoljuk, hogy ez a tényezô az, amin a lehetőség szerint az oktatási rendszernek a pedagógusokkal együttmúködésben munkálkodniuk kell. Azaz felkelteni a diákok érdeklődését a tananyag iránt, rámutatni a hasznosíthatóságukra és a hozzájuk tartozó összefüggésekre, ugyanakkor elképzelhetô, hogy bizonyos tananyagrészek újragondolásával, elhagyásával (ha lehetséges) komoly változásokat lehetne elérni.

A második helyen a túl sok tananyagra panaszkodnak a mintavételi csoporthoz tartózók, ami összefügghet az előzőekben leírtakkal. Mindezt az oktatási rendszer hibái opció követi.

Összességében elmondható, hogy a három legjelentősebb válasz eredményei alapján a diákoknak alapvetôen az oktatással és rendszerével, a tananyagok minőségével és mennyiségével összefüggó okokat jelölik meg demotivációs tényezókként.

\section{Összefoglalás}

Az élethosszig tartó tanulás segítése közös célunk, sokfajta szemlélettel közelíthetjük meg. Sok esetben egy-egy úffajta megvilágítás jelentheti a kulcsot a nagyobb előrehaladás lépcsőjéhez. Az élethosszig tartó tanulást, mint tanulási folyamatot az IPOO-modell alapján elemezve és a tanulással összefüggő tényezőket ezek alapján csoportosítva is érdemes szemlélnünk a leszűrhető kapcsolódásokat és ok-okozati összefüggéseket.

Mindent összevetve elmondható, hogy a diákok legjelentősebb tanulást segítő motivációi olyan hosszú távú tényezôk, amik a boldogulásukkal, a későbbi megélhetésükkel kapcsolatosak. Egy későbbi biztos megélhetés reményében fektetik a képzésekbe az tanulási energiájukat. Nagyrészt felismerik azt, hogy a tanulással a későbbi jövőjük alapjait fektetik le.

Az egész életen át tartó tanulással összefüggésbe hozható, ezt segítő elemek elsősorban az érettségi vizsgát követô életkorban jelennek meg. Ezért cé- lszerű lenne általánosan a szakgimnáziumi évfolyamokban is elôsegíteni a tanulással összefüggő tényezőket.

Mindez a szakmai érdeklődés fejlesztésével együttesen is történhet. Tehát olyan a tanulás hatékonyságát, értelmét és ismeretszerzési, információkeresési tényezők és kompetenciák szintjét felmérő és fejlesztó tevékenységet bevezetni a középfokú oktatás mindennapjaiba, amivel a tanulási hajlandóság növelhetô.

A szakgimnáziumi évfolyamokon tanulók általános problémája a túlzott leterheltség a tanórák heti száma és a tananyagok mennyisége miatt. Az oktatási rendszer alapvetően jó úton jár a közelmúltban lefektetett változásokkal (pl. szakmai érettségi vizsga bevezetése, második szakma ingyenessége, a szakmai kerettantervek átalakítása), melynek hatásai a közeljövőben már biztosan érezhetők lesznek. Mégis érdemes lehet olyan finomhangulásuk, amelynek céljai a lexikális tudás érvényesülésének visszaszorítása, a tananyagok és tantárgyak összefüggéseire és hasznosíthatóságának kiemelésére törekednének.

A tanulás modern IKT alapú támogatása további motivációs tényezőket adhat (Molnár, 2014) (Molnár, 2016).

Az érettségi vizsga elôtti évfolyamokon egy ösztöndíjrendszer kiépítése jelentős motiváció-növekedéssel járna az érintett diákok esetében.

$\mathrm{Az}$ OKJ-s képzések esetében jellemzően a tanulókat még inkább a szakmai elhelyezkedés és az ezzel összefüggő anyagi források előteremtésének lehetôsége motiválja. Egyre inkább előkerül a családfenntartással összefüggő tényező.

Ők már egy újabb képzési szakasz megkezdésével olyan hasznosítható ismereteket szeretnének szerezni, ami a szakmai érdeklődésüket is kielégíti. Szeretnének akár külföldön is boldogulni és a szakmai tudás megszerzése után a nyelvtanulás az elsődleges ismeretszerzési cél, ami hajtja őket.

A gátló tényezők esetében az időhiány a leggyakoribb elem. Természetesen ez jó kibúvó és más tényezők is meglapulhatnak ezen belül, valamint lehetséges, hogy egy általános tanulói idômenedzsment fejlesztéssel és hatékony időbeosztással 
több tevékenység, akár a tanulás is sokak esetében helyet kaphatna a napirendekben.

A szakgimnáziumi tanulók esetében a már említett fejlesztendő területek, mint a hasznosíthatatlan tudásszerzés, a túl sok tananyag és az oktatással összefüggő problémák jelentik az akadályokat. Az ezeken történő változtatásokkal tehát kevesebbeknek menne el a kedve már ebben az időszakban a tanulástól, az akadályokból nem lehetetlen előnyöket és segítő tényezőket kovácsolni. Ezt az is mutatja, hogy a diákok a segitố tényezőkként a gátló tényezők ellenkezőjét jelölték meg (pl. ha változtatni lehetne, akkor az segítené óket).

Az érettségi vizsgát követő képzések esetében egyre inkább a családfenntartással, a munkahellyel és a pénzügyi nehézségekkel összefüggő elemek jelentik a tanulás akadályait. Ezek az oktatással más nézőpontból függenek össze, így ezeket más szempontból célszerú elemezni.

\section{Köszönetnyilvánitás}

EFOP-3.6.1-16-2016-00003 $K+F+I$ folyamatok hosszú távú megerösitése a Dunaújvárosi Egyetemen projekt által finanszírozott kutatás.

\section{Irodalom}

2011. évi CLXXXVII. törvény a szakképzésről (2011)

87.TV (letöltés: 2018.11.22.)

Budapesti Gépészeti Szakképzési Centrum (2017): Ingyenes 120 órás angol és német nyelvtanfolyamok, https://whttps://net.jogtar.hu/jogszabaly ?docid=a11001ww.gszc.hu/vekop851info (utolsó letöltés: 2018.11.22.)

Gőgh Előd (2018): A legjelentôsebb motiváló tanulási tényezók vizsgálata az élethosszig tartó tanulás szempontjából, III. Kárpát-medencei Oktatási Konferencia, Nagyvárad, Románia megjelenés alatt.

György Molnár, Zoltán Szűts (2014): Advanced mobile communication and media devices and applications in the base of higher education, IEEE 12th International
Symposium on Intelligent Systems and Informatics, Subotica, Szerbia, 169-174.

György Molnár (2016): The Impact of Modern ICTbased Teaching and Learning Methods in Social Media and Networked Environment, 11th International Scientific Conference on Distance Learning in Applied Informatics, Štúrovo, Szlovákia. 341-350.

HVG Eduline (2017): De mi az a szakgimnázium? Kinek való, és kinek nem?,http://eduline.hu/kozoktatas/2017/12/7/ De_mi_az_a_szakgimnazium_3OMRT8(letöltés: 2018.11.22.)

HVG Eduline (2017): Szakgimnáziumok átalakítás után: kinek való ez az iskolatípus, és kinek nem?,http://eduline.hu/kozoktatas/2017/12/23 /szakgimnaziumok_B5UJQC (letöltés: 2018.11.22.)

Magyarország Kormánya (2014): Az egész életen át tartó tanulás szakpolitikájának keretstratégiája a 2014/2020 közötti időszakra, http://www.kormany.hu/download/7/fe/20000 $/ \mathrm{Eg} \% \mathrm{C} 3 \% \mathrm{~A} 9 \mathrm{sz} \% 20 \% \mathrm{C} 3 \%$ A9leten $\% 20 \% \mathrm{C3} \% \mathrm{~A}$ $1 \mathrm{t} \% 20 \operatorname{tart} \% \mathrm{C} 3 \% \mathrm{~B} 3 \% 20$ tanul $\% \mathrm{C} 3 \% \mathrm{~A} 1$ s.pdf(letöl tés: 2018.11 .22 .)

Mező Ferenc (2011): Tanulás: diagnosztika és fejlesztés az. IPOO-modell alapján. K+F Stúdió Kft., Debrecen.

Mező, F. és Mező, K. (2005): Tanulási stratégiák fejlesztése az IPOO-modell alapján. Debrecen: Kocka Kör Tehetséggondozó Kulturális Egyesület.

Molnár György (2014): Az újmédia digitális, idôszerú, tartalmi kérdései, Oktatás-Informatika, VI. 2, 29-39.

Nemzeti Szakképzési és Felnőttképzési Hivatal (2018): Az ágazati szakmai érettségi vizsgáról 2018-ban,

https://www.nive.hu/index.php? option $=$ com_content\&view $=$ article\&id $=912:$ szakm ai-erettsegi-2018\&catid=9\&Itemid=166(letöltés: 2018.11.22.)

Palotás József (2016): Az átalakított szakképzési rendszer jellemzői, működése, http://www. bkmkik.hu/attachments/article/2022/Palot\%C3 \%A1s\%20J\%C3\%B3zsef_2016_11_16.pdf(letölté s: 2018.11.22.) 